\title{
Statyba
}

\section{ANALYSIS OF FIRES AND RESCUE WORK IN LITHUANIA}

\section{P. Čyras \& M. Griškevičius}

To cite this article: P. Čyras \& M. Griškevičius (2001) ANALYSIS OF FIRES AND RESCUE

WORK IN LITHUANIA, Statyba, 7:3, 254-261, DOI: 10.1080/13921525.2001.10531732

To link to this article: https://doi.org/10.1080/13921525.2001.10531732

曲 Published online: 30 Jul 2012.

Submit your article to this journal $\widetilde{ }$

Џ Article views: 69

4 Citing articles: 1 View citing articles 준 


\title{
GAISRŲ IR GELBĖJIMO DARBŲ LIETUVOJE ANALIZE்
}

\author{
P. Čyras, Vilniaus Gedimino technikos universitetas, \\ M. Griškevičius, Priešgaisrinès apsaugos ir gelbẻjimo departamentas
}

\section{Ivadas}

Rizika, fizinè ir nervinè itampa kasdien lydi ugniagesių gelbètojų darbą. Jų darbo sąlygos turi atitikti organizmo psichofiziologinius reikalavimus [1]. Žmonių likimai kilus gaisrui ar atsitikus kitai nelaimei priklauso nuo to, kaip skubiai ugniagesiai gelbètojai atvyksta gavę aliarmo signala. Jie privalo susiruošti per vieną minutę. Per tą laiką komanda turi susirinkti i garažą, užsivilkti specialią apranga, susèsti $\mathfrak{i}$ automobilius ir išvykti. Apie patiriamą stresa, riziką ugniagesiai gelbètojai nèrā linkę kalbèti. Užsienio šalyse atlikti tyrimai rodo, kad ugniagesių gelbètojų darbas priskiriamas pačių pavojingiausių specialybių kategorijai [2]. Metai iš metu jie atlieka vis sudètingesnius ir ivvairesnius gelbèjimo darbus. Šiuo metu priešgaisrinès gelbejjimo tarnybos aprūpinamos naujomis radijo ryšio priemonèmis, modernia gelbejjimo technika ir iranga, apsaugos aparatais ir darbo drabužiais. Gaisruose naudojami didelio slègio siurbliai ir labai efektyvūs vandens purslų švirkštai. Taip sumažinamos vandens sąnaudos, mažiau užpilamos patalpos ir mažiau sugadinama turto.

Tobulesnè technika ugniagesiams gelbètojams leidžia kokybiškiau ir greitai atlikti užduoti. Tai viena iš geriausių investicijų šiais nelengvais mūsų šalies ekonomikai laikais.

Šio darbo tikslas - pateikti pastaruju metu gaisru statistikos analizę ir išryškinti jos tendencijas.

\section{Gaisry statistiné analizė}

Gaisru skaičiaus dinamika nuo $1995 \mathrm{~m}$. pavaizduota 1 pav. Palyginti su $1998 \mathrm{~m}$. [3], $1999 \mathrm{~m}$. gaisru padaugèjo net $50,2 \%$, o ju padaryti nuostoliai - 10,4\%. Ugnis sunaikino 1006 pastatus $21251 \mathrm{~m}^{2}$ gyvenamojo ploto ir $23510 \mathrm{~m}^{2}$ šio ploto buvo sugadinta, 215 autotransporto priemonių, $6690 \mathrm{t}$ pašaru, $404 \mathrm{t}$ grūdų ir kitụ techninių kultūrų, 1965 arus pasèlių. Liepsnose ir dūmuose žuvo 502 naminiai gyvuliai bei 683 paukščiai.

1999 m. gaisruose žuvo 202 žmonių (1998 m. 238), iš jų 13 vaikụ (21), 214 žmonių (179) buvo traumuoti. 118 žmoniu žuvo kaimo vietovėse, o miestuose - 84. Šalies vidurkis 10000 gyventoju buvo 37,8 gaisro, kaime jis siekè 65,81 .

$1999 \mathrm{~m}$. Lietuvoje 10,11\% padaugejjo tyčiniu padegimų, dèl jų kilo 523 gaisrai, kurie padaré nuostoliu už 3649649 Lt. Padegimai sudare 3,74\% visų gaisru. Dėl šios priežasties žuvo 3 žmonès. 9 patyrè traumas. Iš keršto ir pavydo dažniausiai buvo padeginèjamos privačios imonès, gyvenamieji namai, butu durys, sodo nameliai, automobiliai, ùkiniai pastatai. Daugiausia padegimų iregistruota Klaipedoje (80), Vilniuje (67), Šiauliuose (36), Panevėžyje (32) ir Vilniaus rajone (30). Gaisrų ir jụ nuostolių, nukentẻjusių žmonių, tarp jų ir vaiku, statistika pagal apskritis pateikta 1 lenteleje.

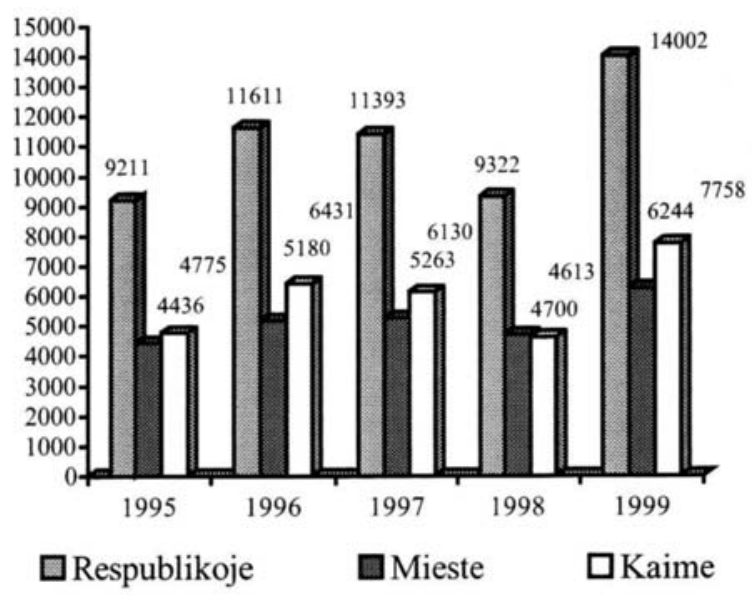

1 pav. Gaisru skaičiaus dinamika

Fig 1. Dynamics of fire numbers 
1 lentelè. Gaisringumas ir nuostoliai Lietuvos apskrityse

Table 1. Rate of fires in districts of Lithuania

\begin{tabular}{|c|c|c|c|c|c|c|c|c|c|c|c|c|}
\hline Apskritis & $\begin{array}{c}\text { Gaisry } \\
\text { skaičius } \\
1998 \mathrm{~m} .\end{array}$ & $\begin{array}{c}\text { Nuosto- } \\
\text { liai } \\
1998 \mathrm{~m} ., \\
\text { tūkst. Lt }\end{array}$ & $\begin{array}{l}\text { Gaisru } \\
\text { skaičius } \\
1999 \text { m. }\end{array}$ & $\begin{array}{c}\text { Nuosto- } \\
\text { liai } \\
1999 \text { m., } \\
\text { tūkst. Lt. }\end{array}$ & $\begin{array}{c}\text { Žuvo } \\
\text { žmoniụ } \\
1998 \mathrm{~m} .\end{array}$ & $\begin{array}{c}\text { Žuvo } \\
\text { žmonių } \\
1999 \mathrm{~m} .\end{array}$ & $\begin{array}{c}\text { Tarp ju } \\
\text { vaiku } \\
1998 \mathrm{~m} .\end{array}$ & $\begin{array}{c}\text { Tarp ju } \\
\text { vaiku } \\
1999 \mathrm{~m} .\end{array}$ & $\begin{array}{c}\text { Trau- } \\
\text { muota } \\
1998 \mathrm{~m} .\end{array}$ & $\begin{array}{c}\text { Trau- } \\
\text { muota } \\
1999 \mathrm{~m} .\end{array}$ & $\begin{array}{c}\text { Gaisru } \\
\text { skaičius } \\
10000 \\
\text { gyventoju }\end{array}$ & $\begin{array}{c}\text { Nuostoliai } \\
10000 \\
\text { gyventojų, } \\
\text { tūkst. Lt }\end{array}$ \\
\hline Vilniaus & 2126 & 4875,26 & 3273 & 4438,16 & 60 & 45 & 7 & 1 & 52 & 37 & 36,58 & 49,67 \\
\hline Kauno & 1554 & 3041,16 & 2430 & 3135,16 & 53 & 37 & 3 & 2 & 41 & 58 & 32,22 & 41,57 \\
\hline Utenos & 786 & 1247,71 & 1493 & 1895,83 & 21 & 16 & 1 & 0 & 7 & 6 & 74,06 & 94,05 \\
\hline Alytaus & 624 & 1376,74 & 855 & 1369,10 & 14 & 10 & 2 & 1 & 5 & 14 & 42,27 & 67,69 \\
\hline Panevėžio & 935 & 2287,12 & 1381 & 2569,08 & 8 & 16 & 1 & 0 & 11 & 32 & 42,82 & 79,66 \\
\hline Šiauliy & 963 & 1702,50 & 1453 & 1924,08 & 26 & 20 & 4 & 2 & 22 & 23 & 36,14 & 47,86 \\
\hline Tauragès & 266 & 767,67 & 357 & 780,70 & 4 & 5 & 0 & 0 & 1 & 1 & 27,45 & 60,03 \\
\hline Telšių & 420 & 1146,54 & 534 & 2685,12 & 6 & 12 & 1 & 2 & 4 & 12 & 29,26 & 147,11 \\
\hline Klaipèdos & 1175 & 4617,37 & 1668 & 3808,45 & 30 & 22 & 2 & 0 & 23 & 22 & 40,14 & 91,65 \\
\hline Marijampolès & 463 & 685,96 & 544 & 1254,69 & 16 & 19 & 0 & 5 & 13 & 9 & 27,39 & 63,18 \\
\hline
\end{tabular}

\subsection{Gaisrų kilimo vietos}

$1999 \mathrm{~m}$. daugiausia gaisru kilo atvirose teritorijose, miškuose, pievose bei durpynuose - 5645, t. y. $40,32 \%$ visu gaisru. Palyginti su 1998 m., gaisru padaugèjo net $145,76 \%$. Toki padidèjimą lèmé pavasari masiškai deginta sausa žolè, vasaros karščiai bei sausra ir užsitęsęs šiltas ruduo. Generalinès mišku urèdijos prie Aplinkos ministerijos duomenimis, $1999 \mathrm{~m}$. Lietuvos miškuose kilo 1017 gaisru (1998 m. - 219), kurie nuniokojo 483 ha žaliojo ploto (1998 m. - 76 ha). Šalies ugniagesiai padèjo užgesinti 702 miškų gaisrus (1998 m. - 134), net 4104 kartus (1998 m. - 1418) vyko gesinti degančios žolès plotu. 1999 m. ypač daug rūpesčių kèlè išaugęs gaisrų skaičius durpynuose - teko gesinti net 199 durpynu gaisrus bei durpingas pievas, tuo tarpu 1998 m. - tik 7.

$35 \%$ visu gaisru (4902) kilo gyvenamajame sektoriuje. Palyginti su $1998 \mathrm{~m}$., ju padaugèjo beveik 7\%, $67,86 \%$, padaugèjo gaisrų žemès ūkio objektuose, $21,23 \%$ jų padaugejo sandèliuose, bazèse ir prekybos imonèse, $13,76 \%$ - statomuose objektuose, $2,41 \%$ - autotransporto priemonèse, o mažiau jų kilo tik gamybiniuose $(-3,47 \%)$ ir gyvulininkystès pastatuose $(-5,17 \%)$. Miestuose jregistruoti 6244 gaisrai, o kaimo vietovèse - 7758. 1999 m. žuvusių žmonių skaičius pagal gaisro kilimo vietą pateiktas 2 ir 3 pav.

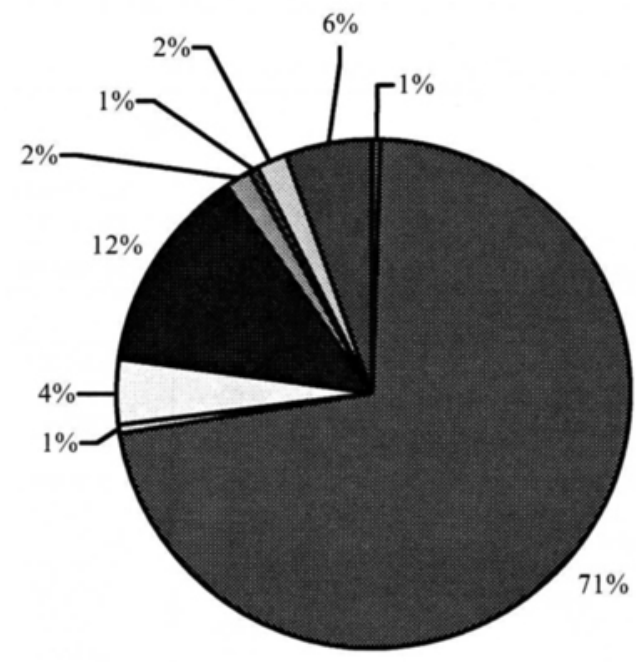

DBalkonas, lodžija - 1 žm. (1\%)

Gyvenamasis kambarys - 117 žm. (71\%)

口Vonia, tualetas - 1 žm. (1\%)

口Koridorius - 7 žm. (4\%)

口irtuvè - 21 žm. (12\%)

$\square$ Laiptinè - 3 žm. ( $2 \%)$

口Rūsys - 1 žm. (1\%)

口Palèpè - 3 žm. (2\%)

口Kitos patalpos - 9 žm. (6\%)

2 pav. 1999 m. žuvusiuju skaičius pagal gaisro kilimo vietą

Fig 2. Number of victims according to fire rising place in 1999 


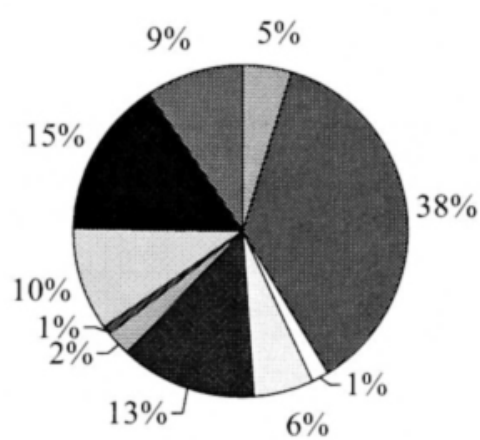

\subsection{Gaisrų padaryti materialiniai nuostoliai}

$1999 \mathrm{~m}$. Lietuvoje kilo 14002 gaisrai, kurie padare nuostoliụ už 24007676 Lt. Bendras gaisrų skaičius šalyje, patirti nuostoliai pinigine ir materialine išraiška, ju priežastys ir palyginamieji duomenys (su $1998 \mathrm{~m}$.) pateikti 2 lentelèje.

2 lentelè. Gaisru skaičius, padariniai ir priežastys (1999 m.) $\square$ Balkonas, lodžija - $117(5 \%)$

Gyvenamasis kambarys - $916(38 \%)$

$\square$ Vonia, tualetas - $37(1 \%)$

$\square$ Koridorius - $151(6 \%)$

- Virtuvè - $326(13 \%)$

$\square$ Sandèliukas - $61(2 \%)$

- Liftas - $22(1 \%)$

- Laiptinè - $246(10 \%)$

- Rūsys - $384(15 \%)$

口Palèpé $-233(9 \%)$

3 pav. 1999 m. gaisrai gyvenamuosiuose namuose pagal jų kilimo vieta

Fig 3. Number of fires in dwelling houses according to fire rising place in 1999

1999 m. padaugejo gaisru, padariusių dideliu materialiniu nuostoliu: iregistruoti 56 gaisrai, kuriu kiekvieno nuostoliai viršijo 50 tūkst. Lt, 21 iš ju nuostoliai siekè per 100 tūkst. Lt, o 8 - daugiau kaip po 200 tūkst. Lt. Be to, kilo du gaisrai, kuriu kiekvieno nuostoliai viršijo vieną milijoną litụ.

Table 2. Number of fires, causes and effects

\begin{tabular}{|c|c|c|c|c|c|c|}
\hline & \multicolumn{2}{|c|}{$1998 \mathrm{~m}}$. & \multicolumn{2}{|c|}{$1999 \mathrm{~m}}$. & \multirow{2}{*}{$\begin{array}{l}\text { Palyginamieji duomenys } \\
\text { (gaisrų skaičiaus), } \%\end{array}$} & \multirow{2}{*}{$\begin{array}{l}\text { Nuo bendro gaisru } \\
\text { skaičiaus, } \%\end{array}$} \\
\hline & $\begin{array}{l}\text { Gaisrų } \\
\text { skaičius }\end{array}$ & $\begin{array}{l}\text { Nuostoliai, } \\
\text { tūkst. } \mathbf{L t}\end{array}$ & $\begin{array}{l}\text { Gaisrų } \\
\text { skaičius }\end{array}$ & $\begin{array}{l}\text { Nuostoliai, } \\
\text { tūkst. Lt }\end{array}$ & & \\
\hline Bendras gaisrų skaičius & 9322 & 21749,00 & 14002 & 24007,68 & 50,20 & 100,0 \\
\hline \multicolumn{7}{|l|}{ Gaisrų kilimo vieta } \\
\hline $\begin{array}{l}\text { Gamybiniai pastatai } \\
\text { Prekybos ịmonés, sandèliai } \\
\text { Žemès ūkio objektai } \\
\text { - daržinés } \\
\text { - gyvulininkystès pastatai } \\
\text { - kiti ž. ū. objektai } \\
\text { Gyvenamasis sektorius } \\
\text { - gyvenamieji namai } \\
\text { - ükiniai pastatai } \\
\text { Naujos statybos } \\
\text { Automobiliai } \\
\text { Atviros teritorijos } \\
\text { Kiti atvejai }\end{array}$ & $\begin{array}{c}288 \\
146 \\
168 \\
29 \\
58 \\
79 \\
4585 \\
2787 \\
1595 \\
109 \\
996 \\
2297 \\
733\end{array}$ & $\begin{array}{c}1401,80 \\
852,61 \\
1147,49 \\
191,57 \\
635,00 \\
320,92 \\
12342,80 \\
6733,80 \\
4769,35 \\
232,70 \\
2640,00 \\
24,86 \\
3106,73\end{array}$ & $\begin{array}{c}278 \\
177 \\
282 \\
42 \\
55 \\
185 \\
4902 \\
2799 \\
1916 \\
124 \\
1020 \\
5645 \\
1574\end{array}$ & $\begin{array}{c}2772,49 \\
2125,06 \\
1825,45 \\
1170,52 \\
219,90 \\
435,02 \\
1454,65 \\
7595,28 \\
5809,75 \\
169,07 \\
2377,37 \\
71,85 \\
611,73\end{array}$ & $\begin{array}{c}-3,47 \\
21,23 \\
67,86 \\
44,83 \\
-5,17 \\
134,18 \\
6,91 \\
0,43 \\
20,13 \\
13,76 \\
2,41 \\
145,76 \\
114,73\end{array}$ & $\begin{array}{c}1,99 \\
1,26 \\
2,01 \\
0,30 \\
0,39 \\
1,32 \\
35,01 \\
19,99 \\
13,68 \\
0,89 \\
7,28 \\
40,32 \\
11,24\end{array}$ \\
\hline \multicolumn{7}{|l|}{ Gaisrų priežastys } \\
\hline $\begin{array}{l}\text { Padegimai } \\
\text { Technologiniai pažeidimai } \\
\text { Elektros ịrangos naudojimas } \\
\text { Krosnių naudojimas } \\
\text { Neatsargus elgesys su ugnimi } \\
\text { Vaikų žaidimai su ugnimi } \\
\text { Nenustatytos priežastys } \\
\text { Kitos priežastys }\end{array}$ & $\begin{array}{c}475 \\
102 \\
1507 \\
838 \\
3829 \\
850 \\
511 \\
1210\end{array}$ & $\begin{array}{l}5426,58 \\
241,56 \\
5888,38 \\
1851,08 \\
2336,89 \\
1018,95 \\
866,73 \\
4118,83\end{array}$ & $\begin{array}{c}523 \\
203 \\
1549 \\
976 \\
6953 \\
1275 \\
983 \\
1540\end{array}$ & $\begin{array}{c}3649,65 \\
1794829 \\
6424,22 \\
2135,03 \\
2856,28 \\
890,24 \\
2012,59 \\
3362,35\end{array}$ & $\begin{array}{c}10,11 \\
99,02 \\
2,79 \\
16,47 \\
81,59 \\
50,00 \\
92,37 \\
30,57\end{array}$ & $\begin{array}{c}3,74 \\
1,45 \\
11,06 \\
6,97 \\
49,66 \\
9,11 \\
7,02 \\
11,0\end{array}$ \\
\hline \multicolumn{7}{|l|}{ Gaisru padariniai } \\
\hline $\begin{array}{l}\text { Žuvo žmonių } \\
\text { Iš jų vaikų } \\
\text { Traumuota } \\
\text { Sunaikinta: } \\
\text { - pastatụ } \\
\text { - gyvuliụ } \\
\text { - automobiliu ir kt. technikos } \\
\text { - grūdu ir techninių kultūrų (t) } \\
\text { - pašarų (t) } \\
\text { - daržiniụ } \\
\text { - gyvenamojo ploto (m²) } \\
\text { Sugadinta gyvenamojo ploto }\left(\mathrm{m}^{2}\right)\end{array}$ & \multicolumn{2}{|c|}{$\begin{array}{c}238 \\
21 \\
179 \\
\\
839 \\
580 \\
257 \\
1134 \\
4182 \\
11 \\
21797 \\
20135\end{array}$} & & $\begin{array}{l}2 \\
3 \\
14 \\
06 \\
2 \\
5 \\
4 \\
90 \\
3 \\
251 \\
510\end{array}$ & $\begin{array}{r}-15,13 \\
-38,10 \\
-19,55 \\
19,90 \\
-13,45 \\
-16,34 \\
-64,37 \\
59,97 \\
109,09 \\
-2,50 \\
16,76\end{array}$ & \\
\hline
\end{tabular}




\subsection{Gaisrų priežastys}

Pagrindinès gaisru priežastys (4 pav.): neatsargus elgesys su ugnimi $(49,66 \%)$, elektros irenginių eksploatacijos taisyklių pažeidimai (11,06\%), vaikų žaidimai su ugnimi $(9,11 \%)$, krosnių naudojimo gaisrinès saugos taisykliu pažeidimai $(6,97 \%)$, padegimai $(3,74 \%)$, technologiniai pažeidimai $(1,45 \%)$, kitos priežastys $(11 \%)$. 1999 m. 92\% padaugèjo nenustatytu gaisro priežasčiu. Tokių gaisru kilo 983 , t. y. $7,02 \%$ visų gaisrų.

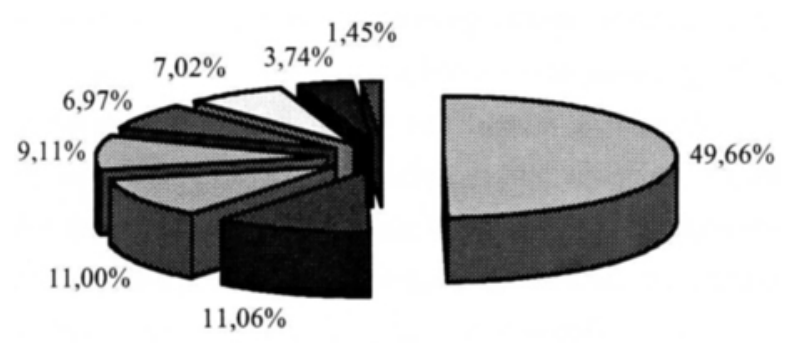

4 pav. 1999 m. kilusių gaisru priežastys (\%)

Fig 4. Causes of fires in 1999

\section{4. Žmonių žūtis gaisruose}

1999 m. gaisruose žuvo 202 žmonès, iš ju 13 vaikú. Dar 214 žmonių buvo traumuoti, tarp ju ir 9 ugniagesiai. Taigi gaisruose žuvo 36 suaugusiais žmonèmis $(-15,13 \%)$ ir 8 vaikais $(-38,1 \%)$ mažiau negu 1998 m. [3]. Tačiau $19,55 \%$ padaugèjo gaisruose patyrusiu traumas asmenu. Beveik kas 69 -ame gaisre žuvo žmogus, o kas 65-ame patirtos traumos. 179 gaisruose žuvo po žmogu, o gaisru, kuriuose žuvo du ir daugiau žmonių, $1999 \mathrm{~m}$. buvo 21 (1998 m. - 23).

$1999 \mathrm{~m}$. miestuose liepsnose žuvo 10 suaugusiu žmoniu ir vienu vaiku daugiau, palyginti su $1998 \mathrm{~m}$. Kaime šis rodiklis buvo geresnis: žuvo 46 žmonèmis mažiau, perpus mažiau žuvo vaiku. Tačiau situacija kaime išlieka sudètinga: iš $131999 \mathrm{~m}$. gaisruose žuvusiu vaiku, 9 sudegè arba užtroško dūmuose kaimo sodybose. Palyginti su $1998 \mathrm{~m}$. [3], kaimo vietovèse gaisru padaugèjo net $68,2 \%$. Tą lemia sunkios ekonominès ir socialinès sąlygos kaime: vaiku darželiu stygius, prastas telefono ryšys, pavèluoti pranešimai apie ivykius, blogi keliai, neremontuojamos krosnys ir dūmtraukiai, žaibolaidžiai, didejantis nedarbas, girtavimas ir kt. Tik 1992 m. gaisru aukų daugiau buvo miestuose negu kaime. Miestuose ir kaimuose gaisruose žuvusių suaugusių žmoniu ir vaikų skaičius pateiktas 5 pav.

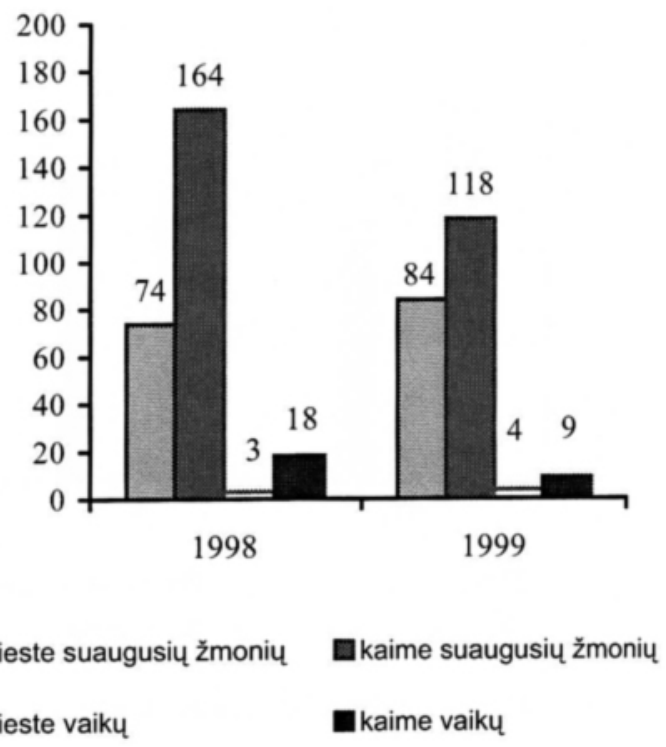

5 pav. Gaisruose žuvusių suaugusių žmonių ir vaikụ skaičius

Fig 5. Number of people and children dead in fires

1999 m. sumažèjo grupinio žuvimo atvejų: iregistruota 19 gaisrug, kuriuose žuvo po du žmones, bei 2 gaisrai, kuriuose žuvo po tris žmones.

6 pav. pateikti gaisruose žuvusių žmonių, tarp jų ir vaiku, taip pat išgelbètų ir traumuotu, skaičiai.

Atlikus gaisru statistinę analizę, nustatytos žmoniu ir vaikų žuvimo gaisruose aplinkybès. Daugiausia nelaimiu ivyksta girtaujant ir miegant (7 pav.).

\section{Gelbẻjimo darbai}

$1999 \mathrm{~m}$. Lietuvos Respublikos priešgaisrinès gelbejjimo tarnybos atliko 5781 gelbejjimo darbą. Palyginti su 1998 m., gelbèjimo darbu padaugèjo 19,6\%.

Analizuojant atliktŭ gelbèjimo darbu statistiką (8 pav.), matyti, kad 37,4\% visų atliekamu darbu tenka pagalbai buityje: durų atidarymas, vandens vežimas, kanalizacijos prapūtimas, automobiliụ buksyravimas, vandens išsiurbimas ir pan., ir $15,78 \%$ kitiems darbams. Tačiau, palyginti su ankstesniais metais, pagalba buityje sumažèjo. Tai rodo, kad mažèja netiesiogiai su gelbèjimu susijusių darbų skaičius. $1999 \mathrm{~m}$. ugniagesiai gelbètojai 14 kartụ skubèjo ì pagalbą skęstantiesiems ir išgelbëjo 9 žmones. 139 kartus ugniagesiai buksyravo sudaužytus automobilius, 298 kartus iš įvairiụ vietụ traukẻ sudaužytus automobilius, 100 kartu plovè autoavarijụ metu išsiliejusi benziną arba tepalus, naudodami gel- 


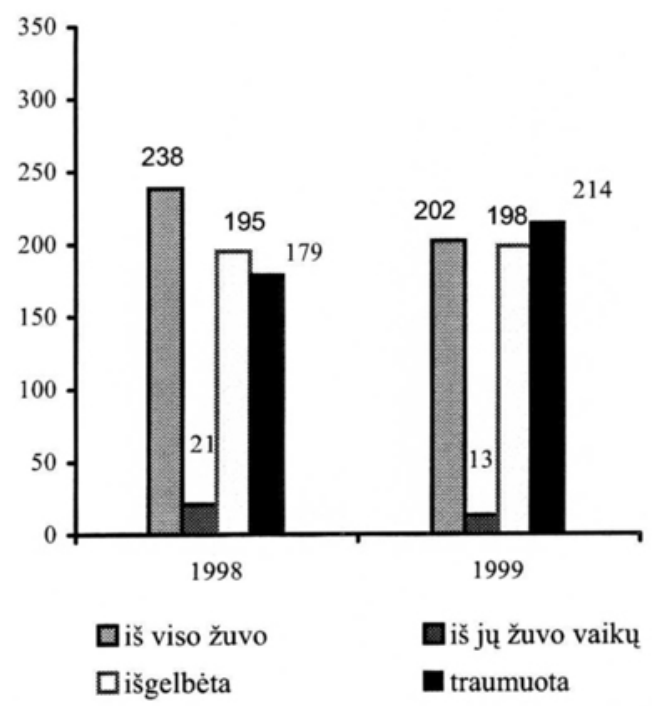

6 pav. Gaisruose žuvusių žmoniu skaičius

Fig 6. Number of fire victims

bẻjimo irangą iš sudaužytų automobilių išgelbèjo 237 nukentèjusiuosius ir ištraukè 156 žuvusius žmones [4].

Vis dažniau ugniagesiams tenka likviduoti cheminių avariju padarinius. $1999 \mathrm{~m}$. jie du kartus stabdè chemines reakcijas chemikalų sandèliuose, viena kartą likvidavo cheminiu avariju padarinius transportuojant chemikalus geležinkeliu, vieną kartą gabenant automobiliu transportu ir 10 kartu likvidavo chemines avarijas buityje. Išsiliejusių naftos produktų avarijas ugniagesiai likvidavo 17 kartų (iš jų vieną avariją degalinèje). Per
$1999 \mathrm{~m}$. priešgaisrinès gelbèjimo tarnybos 169 kartus atliko demerkurizavimo darbus. Palyginti su 1998 m., šiu darbu atlikta $28,4 \%$ daugiau [3]. Daugiausia demerkurizacijos atveju buvo dideliuose miestuose. Priešgaisrinèse gelbẻjimo tarnybose isteigus ugniagesiu gelbètoju naru tarnybas, padaugèjo skenduolių paieškos atveju (palyginti su $1998 \mathrm{~m}$., jụ padaugèjo 40\%). 1999 m. ugniagesiai gelbètojai ištraukè 239 skenduolius. Neretai jiems tenka atlikti ir kitokius darbus: nukelti žmones nuo namu stogų, nuimti pavojingai kabančius reklaminius stendus, iškelti gyvulius iš duobiu ir šulinių, nukelti gyvūnus nuo medžių.

Padažnèjo atvejŭ kai priešgaisrinès gelbèjimo tarnybos važiuoja atlikti gelbèjimo darbus iškviestos kitų specialiuju tarnybu. $1999 \mathrm{~m}$. užregistruoti net 846 tokie atvejai, jụ skaičius, palyginti su $1998 \mathrm{~m}$., padidèjo 7\%.

Nuolat daugeja atveju, kai ugniagesiams gelbètojams tenka atidaryti užsitrenkusias duris, vežti vandeni, vykti i vandentiekio arba kanalizacijos avarijas, buksyruoti automobilius, traukti automobilius iš grioviu (ypač žiemos laikotarpiu) ir likviduoti ìvairias buitines avarijas. Tokių atvejų 1999 metais buvo 2161.

Po priešgaisrinès apsaugos reformos žymiai pagerèjo padaliniu operatyvumas. Gaisro gesinimo vadovais 6197 gaisruose buvo pamainu vadovai (9 pav.). Daugiau negu $1998 \mathrm{~m}$. likviduota gaisru tik su dviem švirkštais, sumažèjo gaisrinių automobilių atvykimo laikas

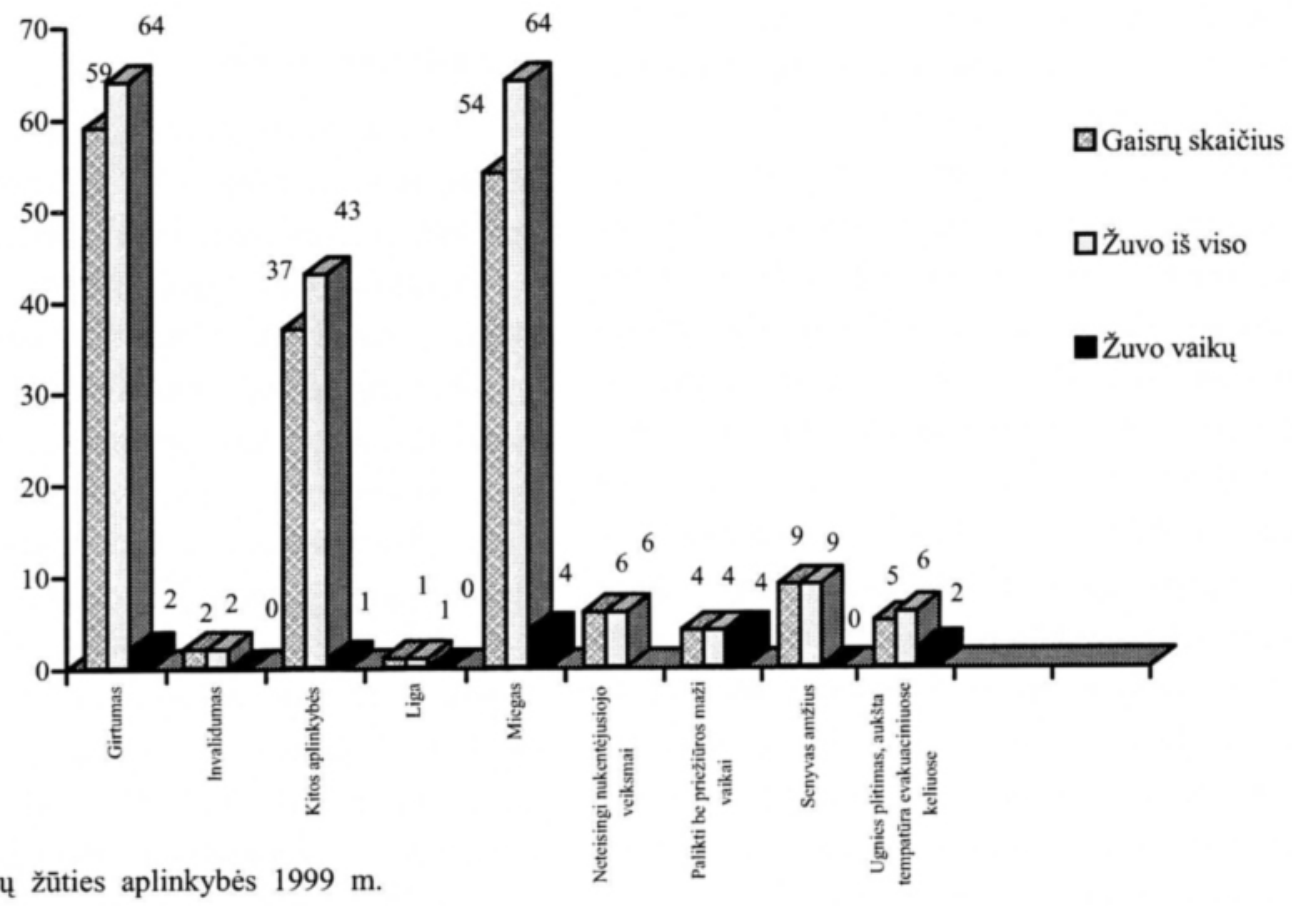

7 pav. Žmonių žūties aplinkybẻs $1999 \mathrm{~m}$

Fig 7. Circumstances of death in fires in 1999 


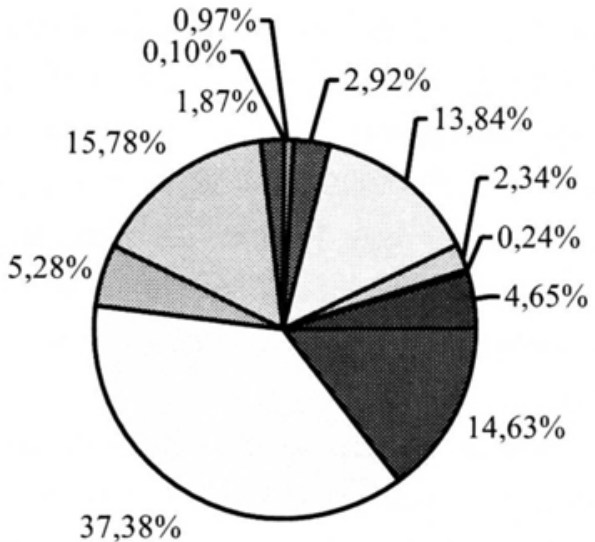

8 pav. 1999 m. atlikti gelbèjimo darbai
口Cheminių avarijų likvidavimas - 56 (0,97\%)

口Demerkurizacija - 169 (2,92\%)

$\square$ Gelbèjimo darbai autoavarijose - $800(13,84 \%)$

$\square$ Apsauga nukenksminant sprogmenis - $135(2,34 \%)$

QSkęstančiuju gelbèjimas - $14(0,24 \%)$

Darbai aukštyje - 269 (4,65\%)

$\square$ Pagalba specialiosioms tarnyboms - $846(14,63 \%)$

口Pagalba buityje - $2161 \quad(37,38 \%)$

口Skenduolių paieška - $305(5,28 \%)$

口Kiti - 912 (15,78\%)

Gelbèjimo darbai vandenyje - $108(1,87 \%)$

Darbai su radioaktyviosiomis medžiagomis - $6(0,10 \%)$

Fig 8. Classification of rescue works performed in 1999

(10 pav.). Daugiau kaip $40 \%$ visų gaisrų užgesinama greičiau nei per 10 minučiu ir tik $7 \%$ gaisru gesinami ilgiau kaip valandą (11 pav.).

\section{Priešgaisrinès gelbẻjimo tarnybos pajẻgos}

$2000 \mathrm{~m}$. sausio $1 \mathrm{~d}$. Lietuvoje statutiniais pagrindais dirbančioje priešgaisrinèje gelbejjimo tarnyboje buvo 4412 etatu, iš jų 933 karininku, 3109 eiliniu ir pus-

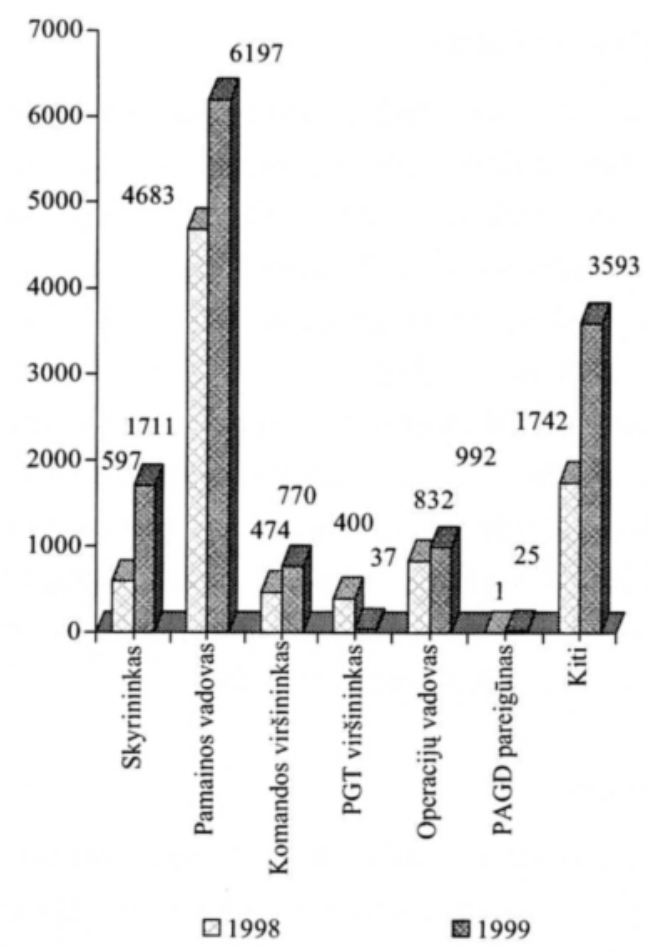

9 pav. Incidentu likvidavimo vadovai

Fig 9. Leaders of incidents elimination karininkiu, 370 dirbančiu samdos pagrindais. Miestu priešgaisrinę gelbejjimo tarnybą sudaro 44 padaliniai (3768 etatai, iš ju 690 karininku, 2775 eilinių ir puskarininkiu bei 303 samdomy darbuotojų). Šalies svarbiausių ūkio objektų - AB „Mažeikių nafta“, Ignalinos $\mathrm{AE}$, Lietuvos elektrinès gaisriñę saugą uzžtikrina 3 priešgaisrinès gelbẻjimo tarnybos (430 etatu, iš jų 94 karininku, 317 eilinių ir puskarininkiu, 19 samdomų darbuotoju). Nestatutiniais pagrindais dirbančioje priešgaisrinejje tarnyboje yra 715,5 etato.

Iš savivaldybių biudžeto išlaikomos 262 ugniagesių komandos, turinčios 2225 etatus.

269 karininkų $(28,8 \%)$ ir 1402 eilinių bei puskarininkių $(45,1 \%)$ amžius nesiekia 30 metu. Nuo 31 iki

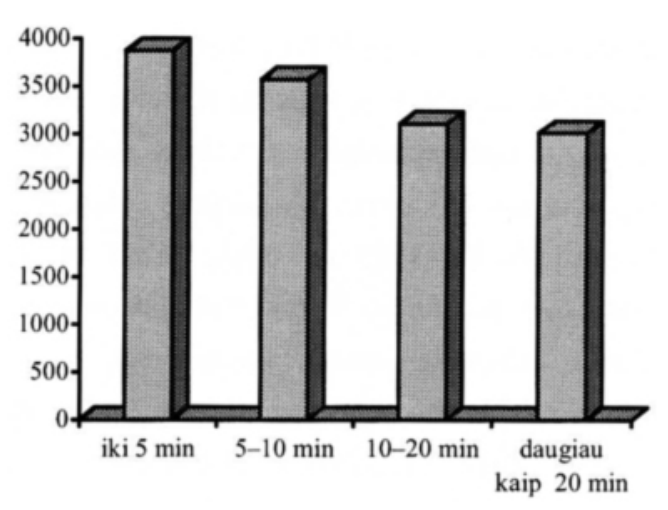

10 pav. Gaisrinių automobilių atvykimo laikas

Fig 10. Arrival time of fire trucks 


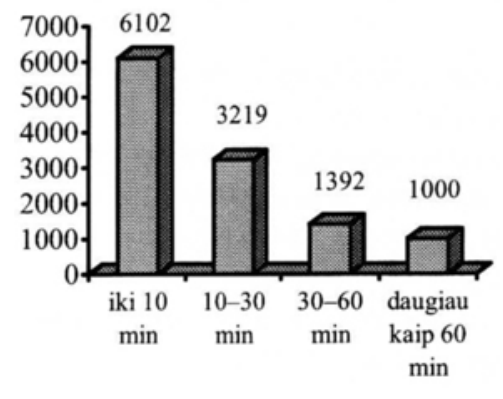

11 pav. Gaisru lokalizacijos laikas

Fig 11. Fire localisation time

45 metu turi 556 karininkai $(60 \%)$ ir 1527 eiliniai bei puskarininkiai (49\%), o nuo 46 iki 50-37 karininkai $(4 \%)$ ir 18 eiliniu bei puskarininkiu $(0,6 \%)$.

Vykdant civilinès saugos istatymą ir gerinant Priešgaisrinès apsaugos ir gelbèjimo departamento padaliniu struktūrinę bei funkcinę sistemas, $1999 \mathrm{~m}$. gegužès $17 \mathrm{~d}$. vidaus reikalu ministro isakymais $\mathrm{Nr} .316$ ir 317 , Lietuvos Respublikos sukarinta priešgaisrinė apsauga reorganizuota i priešgaisrinę gelbejjimo tarnybą. Šiais isakymais siekiama pereiti prie vienos priešgaisrinès gelbejjimo tarnybos, kurioje tarnautu atestuoti pareigūnai.

Siekiant dalyvauti Europos ir pasaulio tarptautinèse bendrijose, plètojantis ugniagesybai ir gelbejjimo darbams, priešgaisrinèse gelbèjimo tarnybose numatoma tobulinti darbuotojų rengimo sistemą, palaipsniui pereinant prie plataus profilio ugniagesio gelbètojo rengimo.

\section{Prevencinis darbas}

1999 m. gaisrų šalyje padaugèjo, todèl nemaža darbo laiko valstybinès gaisrinès priežiüros pareigūnams teko skirti ju tyrimui, medžiagai apie gaisrus surinkti ir iforminti.

Analizuojant administracinio darbo rezultatus, matyti, kad per pastaruosius trejus metus vis mažèjo už gaisrinès saugos taisyklių ir kitų norminių aktu reikalavimų pažeidimus nubaustų asmenų skaičius. Tačiau negalima teigti, kad sumažèjo valstybinès gaisrinès priežiūros pareigūnų reiklumas pažeidèjams. Nestabili ekonominè padètis bei $1999 \mathrm{~m}$. šalyje kilusi ekonomine krizè tam taip pat turèjo îtakos. Sumažèjus rentabiliai ir pelningai dirbančių i̇monių, daugelyje jų mažèjo gamybos apimtys, darbuotoju skaičius, kai kurios bankrutavo ir pan. Taigi sumažèjo ir potencialiu pažeidèju. 1999 m. už gaisrinès saugos taisyklių reikalavimų nesilaikymą nubausti 4398 asmenys bendra $349155 \mathrm{Lt}$ suma. Palyginti su 1998 m., baudu skaičius sumažèjo 12\% (4919), o baudu suma - 11\% (388 $165 \mathrm{Lt}$ ). Pareigūnu (darbdavių) nubausta 1048 (1998 m. - 1080), piliečių - 3350 (1998 m. - 3839), t. y. atitinkamai 3\% ir 13\% mažiau negu $1998 \mathrm{~m}$. Iki metu pabaigos i valstybès biudžetą išieškota $286320 \mathrm{Lt}$ iš 4020 asmenu. Tai sudaro $89 \%$ bendro baudu skaičiaus (1998 m. $92 \%$ ).

$1999 \mathrm{~m}$. daugiausia dèmesio buvo skiriama Valstybinès gaisrinès priežiūros nuostatų bei Valstybinès gaisrinès priežiūros darbo organizavimo instrukcijai parengti, valstybinès reikšmès statybu ir svarbiausių objektų priežiūrai vykdyti, valstybinès gaisrinès priežiūros inspekciju, vykdančiu gaisrinę priežiūra, darbo kontrolei. Nuostatu projektą Lietuvos Respublikos Vyriausybè patvirtino $1999 \mathrm{~m}$. gruodžio $23 \mathrm{~d}$. (nutarimas Nr. 1462), o darbo organizavimo instrukcijos projektas pateiktas tvirtinti vidaus reikalų ministrui.

Valstybinès gaisrinès priežiūros skyriaus pareigūnai, vykdydami departamentui pavestas kontrolès funkcijas, atliko svarbiausių strateginių šalies objektų: Ignalinos AE, AB „Mažeikių nafta“, Kruonio HAE, Lietuvos elektrinès, Klaipèdos uosto objektų gaisrinius techninius patikrinimus. Dalyvauta Būtingès naftos terminalo prièmimo eksploatuoti valstybinès komisijos darbe.

\section{Gaisrỵ rodikliai}

Be absoliučių skaičių, gaisru statistikoje nustatyti santykiniai skaičiai. $1999 \mathrm{~m}$. gaisrų dažnio rodiklis sudaro 3,88 (1998 m. - 2,6), vidutinis gaisro nuostolio rodiklis padidejo iki 1715 (1998 m. - 1553), taip pat padidejo gaisru santykinio nuostolio rodiklis, jis sudare 6654 (1998 m. - 4038).

Šie rodikliai charakterizuoja gaisringumo lygi ir jais galima apibūdinti atskiro administracinio vieneto ar respublikos gaisrinę būklę ir palyginti juos su kitų šaliụ rodikliais. Iš pateiktụ duomenų pastebime šių rodikliụ didejjimo Lietuvoje tendenciją. Šis neigiamas veiksnys atspindi šalies ekonomini nuosmukị.

\section{Išvados}

1. Beveik trečdalis $1999 \mathrm{~m}$. užregistruoty gaisru kilo dèl gyventojụ neatsargaus elgesio su ugnimi.

2. Daugiausia gaisru kyla gyvenamajame sektoriuje (4585) ir atvirose teritorijose (2297). 
3. 10 tūkst. šalies gyventojų tenka 37,8 gaisro, o nuostoliu suma siekia $\sim 6700 \mathrm{Lt}$. Kas 69 -ame gaisre netenkama žmogaus, o kas 65-ame yra patiriamos traumos.

4. Prevencinès priemonès gaisringumui mažinti:

- Priešgaisrinès apsaugos ir gelbejjimo departamentui yra tikslinga toliau tęsti gaisriniu apsaugos padalinių reformą.

- Daugiau dèmesio turi būti skiriama prevenciniam darbui, aktyviau turètų reikštis savanoriška gaisrininku draugija.

- Būtina gyventojus supažindinti su gaisrinio saugumo taisyklėmis, gaisrais, ju priežastimis ir pasekmèmis.

5. Pirmosios medicinos pagalbos ekipažus tikslinga kurti priešgaisrinių tarnybų bazèse.

6. Padaliniuose, medicininio punkto bazeje, tai pat ugniagesiu rengimo centre organizuoti ugniagesiu gelbètojų mokymą kaip suteikti pirmają medicinos pagalbą.

7. Gaisrinè sauga yra viena iš pagrindiniu gyventojų civilinio saugumo sistemos daliụ. Tikslinga Priešgaisrinès apsaugos ir gelbejjimo departamentą sujungti su Civilinès saugos departamentu.

\section{Literatūra}

1. В. Кадиров. Основа социологии пожарной безопасности. Москва: Типография академии МВД РФ, 1993. $159 \mathrm{c}$.

2. J. Bednarek, P. P. Bielicki. Podstawy psychologii pedagogiki i metodyki kształcenia pożarnicyego // Firex. Warszawa: Zaklad widawnictw iszkolenia, 1997, s. 7-9.

3. P. Čyras, M. Griškevičius, A. Jaras. Gaisringumo ir gelbéjimo darbų Lietuvoje analizè // Statyba, V tomas, Nr. 2. Vilnius: Technika, 1999, p. 141-147.

4. Gelbējimo darbai, atliekami keliu eismo ivykiu metu / LR VRM PAD. Vilnius: UAB „Saulès vèjas“, 1997. $112 \mathrm{p}$.

Iteikta $2000 \quad 11 \quad 15$

\section{ANALYSIS OF FIRES AND RESCUE WORK IN LITHUANIA}

\section{P. Čyras, M. Griškevičius}

\section{Summary}

In 1999, there were 14002 fires in Lithuania. Their losses reached 24 mill Litas. Comparing with 1998, the number of fires increased by $50,2 \%$ and loss $-10.4 \%$. Fires destroyed 1006 buildings, 215 vehicles, 4,4 tons of grain and other technical cultures.

In 1999, 202 inhabitants died during fires in Lithuania, 13 including children; 214 inhabitants were wounded.
For 10000 inhabitants were 37.8 fires. In 1999 there were $10.11 \%$ arsons in Lithuania. The most of fires were in open places, in forests, in meadows and peat bogs. $35 \%$ of fires occurred in dwelling sector. The essential fire causes are: careless contact with fire $(49.66 \%)$, violation electrical equipment rules $(11.06 \%)$, naughty children $(9.11 \%)$.

4412 duty persons are working in Lithuanian fire and rescue service. Fire and rescue service has 44 branches in the cities. 430 duty persons guard three the most important industrial objects.

202 firemen brigades are financed from the magistrate budgets. They include 2225 staff.

In 1999 State inspectorate for fire prevention worked effectively. New statute, instruction of work organisation was prepared, all-important industrial objects were inspected.

The strategical work of branches was improved. $28 \%$ of fires were eliminated faster than in 15 minutes, the number of fires which elimination takes more than 2 hours decreased.

In 1999, Lithuanian fire and rescue brigades made 5781 rescue works. 800 of them were car accidents, 305 - search for drowned men, and 9 people were saved in the water. Diving training section was established in the firemen training centre.

Officials raise their qualification constantly. 1301 officials have a qualification category. In 1999, 202 privates and 18 officers were trained in the firemen training centre, 980 privates and 206 officers were requalified. 102 officials were retrained with the help of Norway firemen association. 24 Lithuanian officials raised their qualification in Sweden and 22 in Denmark. 51 divers were trained and 74 divers got their rating.

Priorities of work:

- further reorganisation of Fire and rescue service;

- development of legal regulations;

- improvement of fire-fighters training and further qualification raising process;

- widening of rescue works spectrum;

- better supply of technical equipment of Fire brigades.

Petras ČYRAS. Doctor, Associate Professor. Head of Dept of Labour Safety and Fire Protection. Vilnius Gediminas Technical University, Saulètekio al. 11, LT-2040 Vilnius, Lithuania. E-mail: www. Petras Cyras@st.vtu.lt

Doctor (1974). Head of Dept of Labour safety and environment protection (1985-92). Head of Department of Labour safety and fire protection (1993). Research work: manual for students "Ecology and environment protection of road building", 15 study guides, 43 scientific reports. Research interests: labour safety, ergonomics, educology and environmental protection, fire protection.

Mečislavas GRIŠKEVIČIUS. Head of Fire-fighters Training Centre. Fire Protection Department of the Republic of Lithuania, Švitrigailos g. 18, LT-2000 Vilnius, Lithuania.

E-mail: www.m.burd@ vpgt.lt

Research interests: fire protection. 